\begin{tabular}{|c|c|c|c|c|c|}
\hline \multicolumn{6}{|c|}{ DISTRIBUTION SHEET } \\
\hline \multirow{2}{*}{$\begin{array}{l}\text { To } \\
\text { Distribution }\end{array}$} & \multirow{2}{*}{\multicolumn{3}{|c|}{$\begin{array}{l}\text { From } \\
\text { TWRS - Technical Baseline } \\
\text { Integration }\end{array}$}} & \multicolumn{2}{|c|}{ Page 1 of 1} \\
\hline & & & & \multicolumn{2}{|c|}{ Date May 12, 1995} \\
\hline \multirow{2}{*}{\multicolumn{4}{|c|}{$\begin{array}{l}\text { Project Title/Work Order } \\
\text { Historical Model Evaluation Data Requirements }\end{array}$}} & \multicolumn{2}{|c|}{ EDT No. 608028} \\
\hline & & & & \multicolumn{2}{|c|}{ ECN No. } \\
\hline Name & MSIN & $\begin{array}{l}\text { Text } \\
\text { With All } \\
\text { Attach. }\end{array}$ & Text Only & $\begin{array}{l}\text { Attach./ } \\
\text { Appendix } \\
\text { Only }\end{array}$ & $\begin{array}{l}\text { EDT/ECN } \\
\text { Only }\end{array}$ \\
\hline $\begin{array}{l}\text { H. Babad } \\
\text { C. A. Babel } \\
\text { K. E. Bell } \\
\text { G. R. Bloom } \\
\text { T. M. Brown } \\
\text { J. M. Conner } \\
\text { D. A. Dodd } \\
\text { S. J. Eberlein (5) } \\
\text { L. F. Ermold } \\
\text { J. P. Haney } \\
\text { C. S. Homi } \\
\text { L. Jensen } \\
\text { J. Jo } \\
\text { T. J. Kelley } \\
\text { N. W. Kirch } \\
\text { J. G. Kristofzski } \\
\text { M. J. Kupfer } \\
\text { G. J. Lumetta } \\
\text { D. J. McCain (5) } \\
\text { J. E. Meacham } \\
\text { C. H. Mulkey } \\
\text { M. A. Paine } \\
\text { R. S. Popielarczyk } \\
\text { K. M. Remund } \\
\text { L. M. Sasaki } \\
\text { R. D. Schreiber } \\
\text { B. C. Simpson (5) } \\
\text { J. T. Slankas } \\
\text { A. B. Stone } \\
\text { D. M. Strachan } \\
\text { T. C. Trible } \\
\text { D. J. Washenfelder } \\
\text { W. I. Winters } \\
\text { Document Processing Center-North } \\
\text { Central Files (2) }\end{array}$ & $\begin{array}{l}\text { S7-30 } \\
\text { S7-54 } \\
\text { T6-06 } \\
\text { S4-53 } \\
\text { R2-12 } \\
\text { R2-12 } \\
\text { T6-50 } \\
\text { R2-12 } \\
\text { S7-84 } \\
\text { S7-73 } \\
\text { R2-12 } \\
\text { T6-07 } \\
\text { R2-12 } \\
\text { S7-30 } \\
\text { R2-11 } \\
\text { T6-06 } \\
\text { H5-49 } \\
\text { P7-25 } \\
\text { R2-12 } \\
\text { S7-15 } \\
\text { R1-51 } \\
\text { S7-84 } \\
\text { R1-30 } \\
\text { K5-12 } \\
\text { R2-12 } \\
\text { R2-12 } \\
\text { R2-12 } \\
\text { K9-81 } \\
\text { B5-18 } \\
\text { K9-78 } \\
\text { S1-57 } \\
\text { H5-27 } \\
\text { T6-50 } \\
\text { R1-20 } \\
\text { L8-04 }\end{array}$ & $\begin{array}{l}x \\
x \\
x \\
x \\
x \\
x \\
x \\
x \\
x \\
x \\
x \\
x \\
x \\
x \\
x \\
x \\
x \\
x \\
x \\
x \\
x \\
x \\
x \\
x \\
x \\
x \\
x \\
x \\
x \\
x \\
x \\
x \\
x \\
x \\
x\end{array}$ & & & \\
\hline $\begin{array}{ll}\text { O.S.T.I. (2) } \\
\end{array}$ & L8-07 & $x$ & & & \\
\hline M. Dexter & RI-S & $X$ & & & \\
\hline
\end{tabular}




\section{DISCLAIMER}

Portions of this document may be illegible in electronic image products. Images are produced from the best available original document. 
2. To: (Receiving Organization)

Distribution

5. Proj./Prog./Dept./Div.:

75320

8. Originator Remarks:

This Data Quality Objective establishes the need to and methodology of sampling and analyzing high level tank wastes in order to better quantify values associated with historical data.

11. Receiver Remarks:
3. From: (originating Organization)

TWRS - Technical Baseline Integration

6. Cog. Engr.:

B. C. Simpson/D. J. McCain
4. Related EDT No.:

n.a.

7. Purchase Order No.:

n.a.

9. Equip./Component No.:

n.a.

10. Systen/Bldg./Facility:

n.a.

12. Major Assm. Dwg. No.:

13. Permit/Permit Application No.:

14. Required Response Date:

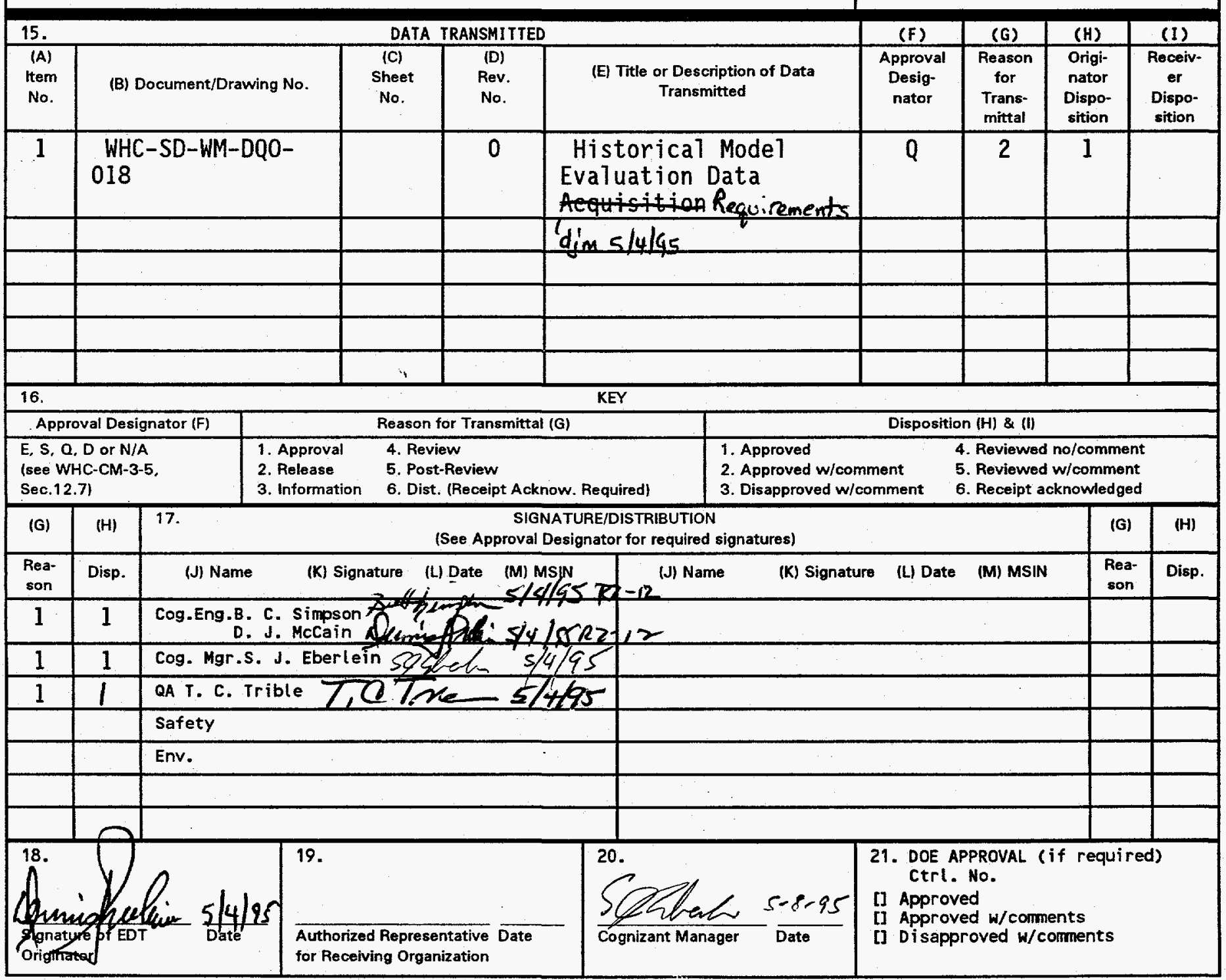




\section{RELEASE AUTHORIZATION}

\begin{tabular}{|ll|}
\hline Document Number: & WHC-SD-WM-DQ0-018, REV 0 \\
\hline Document Title: & Historical Model Evaluation Data Requirements \\
\hline Release Date: & $5 / 4 / 95$ \\
\hline
\end{tabular}

\section{This document was reviewed following the procedures described in WHC-CM-3-4 and is:}

\section{APPROVED FOR PUBLIC RELEASE}

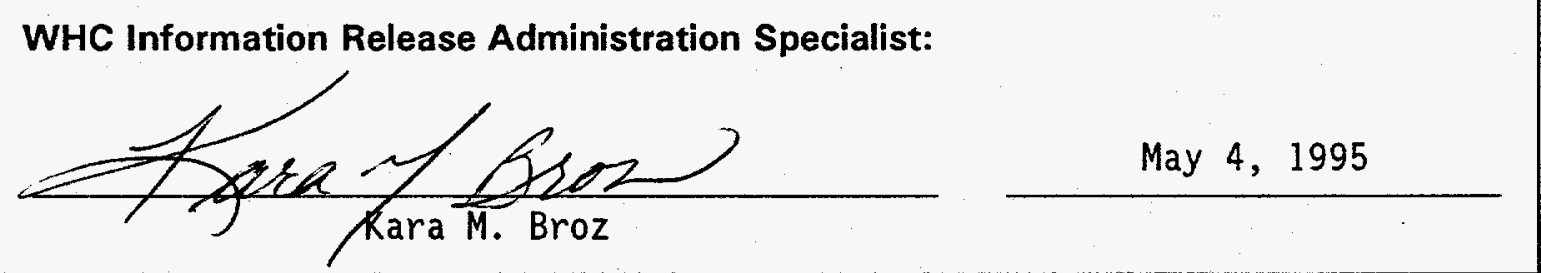

TRADEMARK DISCLAIMER. Reference herein to any specific commercial product, process, or service by trade name, trademark, manufacturer, or otherwise, does not necessarily constitute or imply its endorsement, recommendation, or favoring by the United States Government or any agency thereof or its contractors or subcontractors.

This report has been reproduced from the best available copy. Available in paper copy and microfiche. Printed in the United States of America. Available to the U.S. Department of Energy and its contractors from:

U.S. Department of Energy

Office of Scientific and Technical information (OSTI)

P.0. Box 62

Oak Ridge, TN 37831

Telephone: (615) 576-8401

Available to the public from:

U.S. Department of Commerce

National Technical Information Service (NTIS)

5285 Port Royal Road

Springfield, VA 22161

Telephone: (703) 487-4650 


\section{SUPPORTING DOCUMENT}

1. Total Pages 19

\begin{tabular}{|c|c|c|}
\hline $\begin{array}{l}\text { 2. Title } \\
\text { Historical Model Evaluation Data Requirements }\end{array}$ & $\begin{array}{l}\text { 3. Number } \\
\text { WHC-SD-WM-DQO-018 }\end{array}$ & $\begin{array}{c}\text { 4. Rev No. } \\
0\end{array}$ \\
\hline $\begin{array}{l}\text { 5. Key Words } \\
\text { DQ0, Historical, Fingerprint Analyses, Tank Layer } \\
\text { Model, HTCE, Tank History, Historical Evaluation, } \\
\text { Thick Layer }\end{array}$ & $\begin{array}{l}\text { 6. Author } \\
\text { Name: B. C. Simpso }\end{array}$ & J. Mccain \\
\hline
\end{tabular}

7. Abstract

Historical data describing high level waste tanks at Hanford are incomplete. This DQO establishes a need and directions for sampling from a single waste type, then evaluating the resultant analytical data in conjunction with the historical data.

8. RELEASE STAMP

OFFICIAL RELEASE

BY WHC

DATE

MAY 081995 Atru 4 
WHC-SD-WM-DQO-018, Rev. 0

\title{
Historical Model Evaluation Data Requirements
}

\author{
B. C. Simpson \\ D. J. McCain \\ May 1995 \\ Westinghouse Hanford Company \\ Rich 1 and, Washington
}

\section{DISCLAIMER}

This report was prepared as an account of work sponsored by an agency of the United States Government. Neither the United States Government nor any agency thereof, nor any of their employees, makes any warranty, express or implied, or assumes any legal liability or responsibility for the accuracy, completeness, or usefulness of any information, apparatus, product, or process disclosed, or represents that its use would not infringe privately owned rights. Reference herein to any specific commercial product, process, or service by trade name, trademark, manufacturer, or otherwise does not necessarily constitute or imply its endorsement, recommendation, or favoring by the United States Government or any agency thereof. The views and opinions of authors expressed herein do not necessarily state or reflect those of the United States Government or any agency thereof. 
WHC-SD-WM-DQ0-018, Rev. 0

TABLE OF CONTENTS

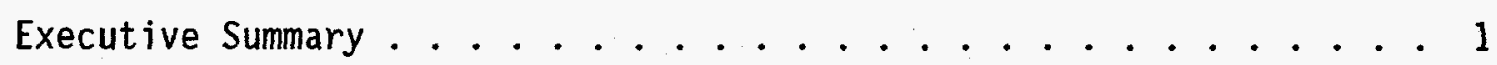

1.0 Statement of Problem ................ 2

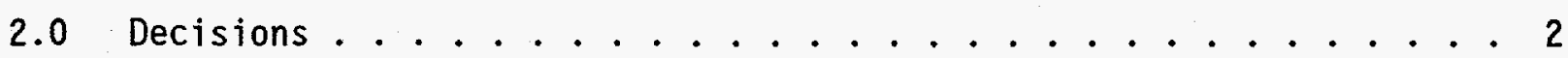

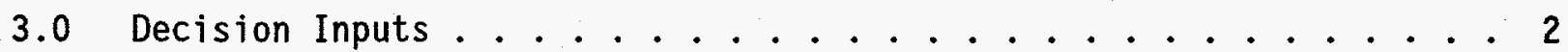

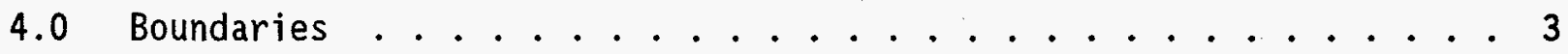

5.0 Decision Rules .................... 10

6.0 Error Tolerance . . . . . . . . . . . . . . 10

7.0 Optimization Guidelines . . . . . . . . . . . 12

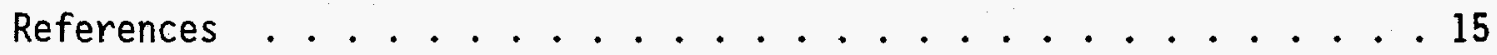

Tables and Figures

Table 1 -- Fingerprint Analytes for Selected Waste Types ..... 5 - 7

Table 2 -- Waste Tanks with Thick Layers ... . . . . . . 8

Table 3 -- Waste Tanks with Shallow Single Wastes or Waste Available for Top Augers ................ . . 9

Figure 1 -- Historical Data Analysis Logic . . . . . . . . . . 11 Table 4 -- Priority Tanks to be Sampled for Historical Evaluation . . . . 14

Appendix A -- Waste Type Acronyms and Descriptions ......... 16 
WHC-SD-WM-DQ0-018, Rev. 0

Executive Summary

Several studies about tank waste contents have been published using historical records of tank transactions and various analytical measurements. While these records offer a wealth of information, the results are questionable until error estimates associated with the results can be established. However, they do provide a direction for investigation. Two principal observations from the studies are:

1) Large quantities of individual waste types from the various separations processes were widely distributed throughout the tank farms, and

2) The compositions of many of these waste types are quite distinct from one another.

A key assumption associated with these observations is that the effects of time and location on the tank wastes are either nominal or not discernable. Since each waste type has a distinct composition, it would benefit all programs to better quantify that composition, and establish an uncertainty for each element of that composition. Various process, disposal, or other decisions could then be made based on current information reducing the need for extended sampling and analysis.

Analysis of the waste types will be accomplished by selecting tanks that have a waste type of interest for processing/storage concerns and is in an easily retrievable configuration. The target is a thick layer of this waste type, so that core sampling will provide segments composed entirely of a single type. Waste type and location confirmation will be established through an initial, or "gateway" review of principal, or "fingerprint" analytes. This review eliminates the need for a more detailed statistical analys is on samples that are clearly not of the desired waste type. Failure during the "gateway" review requires additional assessment of spatial considerations and historical composition data. The result of the review will determine whether a different segment will be assessed, or whether the information that was used to select the tank was incorrect or incomplete.

If the gateway review is favorable (the waste type composition and location match prediction), further quantitative investigation will be performed. A statistical analysis of variability on a wide suite of analytes will be done. The results of the statistical analysis, i.e., means and uncertainty estimates for the analytes from each waste type, will be published. Optimization of the sampling and analysis effort will occur as more information from each waste type is collected and entered into the data base.

At a minimum, information from core composite samples and selected auger samples can also be statistically analyzed. The result can be compared with historical values for total tank contents.

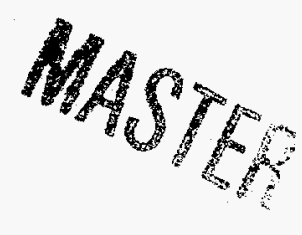


WHC-SD-WM-DQ0-018, Rev. 0

\section{Historical Model Evaluation Data Requirements}

\subsection{Statement of Problem}

Historical records of waste management activities, process design records, and associated measurements taken during those activities have been used to establish estimates of the chemical and radionuclide contents in the tank farms. A key observation used in developing the estimates is that there are "waste types" that can be identified as distinct layers within the tanks (Agnew, 1994a)(Hi11, et.a1., 1995)(See Appendix A). Using these waste types, tanks can be grouped qualitatively by their transaction history and waste types. Furthermore, quantitative estimates of waste inventory could be developed using the volume and composition information for each waste type contained in a tank. The problem is that historical data is not being used to its maximum effectiveness because there are few historical composition estimates with corresponding analytical data. Also, there are no error estimates associated with any waste composition. The primary objective of this DQO is to acquire enough information through selective tank sampling to quantify the errors associated with the predictions for the waste composition. We can then take advantage of information gained from tank grouping models.

\subsection{Decisions}

Two questions are implicit with each waste type investigation:

- Is the waste type a distinct entity as predicted by the model?

- Is the investigated waste type located in the expected position/configuration with in the tank?

Once these two questions have been resolved, information taken from a sampling event may be employed to evaluate means and error estimates from the model predictions in comparison to those from the analytical data. The second question does not require a detailed "thickness" measurement. It requires a confirmation that the segment selected to represent the waste type actually contained the waste. Once these questions have been answered satisfactorily, the decision to use the analytical data for detailed statistical analysis is complete.

\subsection{Decision Inputs}

Information for resolving the questions comes from two sources: the historical modeling data and analytical results from sampling. The decision that the waste type is a distinct entity comes from comparing sample results against a waste type composition matrix created as Table 1 . Each waste type of interest has been listed in the table with concentration of key components for each waste type (Agnew, 1994a). These analytes make up a characteristic profile, or "fingerprint" for that waste type. The presence of a given number of these analytes helps resolve the question whether or not the waste type is a distinct entity. Location of the defined waste type within the tank is similarly determined: conventional interpretation of historical records 
assumes that simple settling occurred during the filling of the tanks--first materials in the tank settle to the bottom and other solids layers were formed chronologically.

Fingerprint analytes for the waste types as listed in Table 1 can generally be determined through three analyses:

1. Inductively Coupled Plasma (ICP)-fusion method for the full range

2. Differential Scanning Calorimetry/Thermogravimetric Analys is (DSC/TGA) for energetics and percent water, and

3. Gamma Energy Analysis (GEA)-fusion for gamma emitting isotope concentrations

NOTE: Although Table 1 would indicate only a few analytes for each of the above analyses, full range reporting for each analysis is requested as an economical factor, in anticipation of passing through the gateway decision parameters.

The above analyses are to be performed on every segment or designated sub-segment of the tank sample. If the fingerprint for the waste type includes other analytes, the following methods are to be used:

4. Ion Chromatography for oxyanions,

5. Total Uranium by fluorimetry, and

$6 . \quad{ }^{90} \mathrm{Sr}$ through separation and beta counting.

All of the above six analyses are needed for historical data evaluation in the event that the segment passes through the gateway review described in Section 5.0, below. Additional analyses needed for a complete historical data evaluation include:

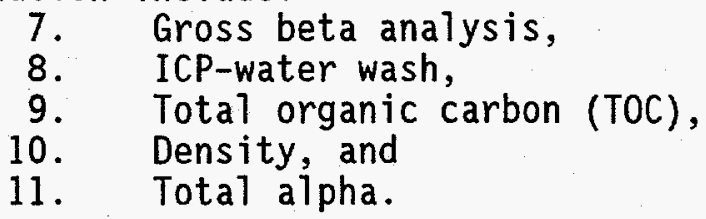

In order to provide for the analytical needs once a segment passes the gateway review, enough material must be archived to allow the complete suite of all eleven analyses to be run.

\subsection{Boundaries}

Analytical estimates of tank contents have been inconclusive when used as the sole source of information regarding tank contents. This is attributed to uncertainties associated with the sampling and/or analytical measurement. To minimize and quantify this uncertainty, the boundary of interest for historical analysis is a predicted layer of a defined waste type. The 1ayer will have significant thickness or be isolated from other waste types. Significant thickness is defined as being thick enough to maximize the possibility that one segment of a core sample will contain nothing but the waste type of interest. If the historical information shows the layer to be 
WHC-SD-WM-DQ0-018, Rev. 0

at least two segments thick, then an appropriate segment can be selected that will most likely be composed of the specified waste type (Agnew, 1994b). Two segments thick roughly translates to a volume of 100,000 gallons (380 cubic meters) of a waste type in a standard 23 meter diameter tank. The waste type is isolated if it can be found on the surface of a waste tank, or if a tank contains only one waste type. A sample from the top (auger sampling) is acceptable, provided enough material is collected for the required analyses without the possibility of contamination with a lower, different waste type.

Tank selection for historical analysis comes from examination of tables 2 and 3 , which list tanks with thick layers, tanks with shallow single waste types, or a waste type accessible in a top layer. Table 4 is a list of high priority tanks that have been determined to be of significant interest for historical evaluation.

If a specific waste type cannot be isolated, there is still value in evaluating analytical information from composite samples formed from all segments in the core sample for each tank. Instead of comparison with the defined waste models, the information can be compared to the Historical Tank Content Estimates (Brevick, et.al., 1994). Composite samples are required for each tank sampled from the list. Four priority tanks (last four on table 4) have been added to this DQO table because they are of a spatially complicated nature, taken for modelling evaluations. 
WHC-SD-WM-DQ0-018, Rev. 0

Table 1

Fingerprint Analytes for Selected Waste Types

\begin{tabular}{|c|c|c|c|c|c|c|c|}
\hline $\begin{array}{l}\text { (ppm) } \\
\text { unless } \\
\text { noted } \\
\text { otherwise }\end{array}$ & MW & $1 C$ & $2 C$ & 224 & UR/TBP & $\mathrm{FeCN}$ & $R$ \\
\hline $\mathrm{Na}$ & 74,400 & $68,000+$ & $\begin{array}{l}37,500 \\
- \\
91,800\end{array}$ & 85,000 & 84,500 & $\begin{array}{r}60,000 \\
-\quad 150,000\end{array}$ & $27,300+$ \\
\hline Al & & $18,300+$ & & & & & $56,400+$ \\
\hline $\mathrm{Fe}$ & & & & & 85,300 & & \\
\hline $\mathrm{Cr}$ & & & & & & & $12,500+$ \\
\hline$B i$ & & $8,500+$ & $20,900+$ & 20,700 & & $25,000+$ & \\
\hline La & & & & 26,700 & & & \\
\hline $\mathrm{Ni}$ & & & & & & $4,000+$ & \\
\hline$\% \mathrm{H}_{2} \mathrm{O}$ & 38.3 & $65.4+$ & 80.0 & 69.0 & 30.4 & $28-81$ & $38-56$ \\
\hline \multicolumn{8}{|l|}{$\mathrm{NO}_{3}$} \\
\hline $\mathrm{CO}_{3}$ & 32,000 & & & & & & \\
\hline $\mathrm{PO}_{4}$ & 30,400 & $68,600+$ & $\begin{array}{l}26,600 \\
- \\
86,000\end{array}$ & & & & \\
\hline $\mathrm{SO}_{4}$ & 56,500 & & & & 112,300 & & \\
\hline$F$ & & & & 46,600 & & & \\
\hline${ }^{137} \mathrm{Cs} \mu \mathrm{Ci} / \mathrm{g}$ & & & & & & $8+$ & $41+$ \\
\hline${ }^{90} \mathrm{Sr} \mu \mathrm{Ci} / \mathrm{g}$ & & & & & & $4+$ & $94+$ \\
\hline$U$ & 164,200 & & & & 50,000 & & \\
\hline
\end{tabular}


WHC-SD-WM-DQ0-018, Rev. 0

Table 1 (Continued)

Fingerprint Analytes for Selected Waste Types

\begin{tabular}{|c|c|c|c|c|c|c|}
\hline (ppm) & CWR/AT & CWP/AT & P & B & CC & AR \\
\hline $\mathrm{Na}$ & 39,000 & $13,800+$ & $\begin{array}{r}48,000- \\
122,500\end{array}$ & 5,800 & $155,000+$ & 72,400 \\
\hline A1 & 95,200 & $88,000+$ & $\begin{array}{r}89,000- \\
105,000\end{array}$ & 22,400 & & 45,700 \\
\hline $\mathrm{Fe}$ & & & & 220,000 & & \\
\hline \multicolumn{7}{|l|}{$\underset{N i}{\mathrm{Cr}, \mathrm{Bi}, \mathrm{La},}$} \\
\hline$\% \mathrm{H}_{2} \mathrm{O}$ & 51.2 & $\begin{array}{l}55.8- \\
56.7\end{array}$ & $\begin{array}{l}60- \\
76.6\end{array}$ & 54.5 & & 72.6 \\
\hline $\mathrm{SO}_{4}$ & & & $\begin{array}{r}7,000- \\
157,000\end{array}$ & & & \\
\hline $\mathrm{SiO}_{3}$ & & & $25,000+$ & & & \\
\hline \multicolumn{7}{|l|}{$F$} \\
\hline${ }^{137} \mathrm{Cs} \mu \mathrm{Ci} / \mathrm{g}$ & & & $50+$ & & & 241 \\
\hline${ }^{90} \mathrm{Sr} \mu \mathrm{Ci} / \mathrm{g}$ & & & & 24,463 & & 11,347 \\
\hline$U$ & 25,500 & $\begin{array}{l}15,100- \\
30,000\end{array}$ & & & & \\
\hline
\end{tabular}


WHC-SD-WM-DQ0-018, Rev. 0

Table 1 (Continued)

Fingerprint Analytes for Selected Waste Types

\begin{tabular}{|c|c|c|c|c|c|c|c|c|c|}
\hline (ppm) & B Salt & T1 salt & R Salt & T2 Salt & BY Salt & s1 salt & s2 salt & A1 Salt & A2 salt \\
\hline $\mathrm{Na}$ & 137,500 & $144,000+$ & 147,000 & 167,400 & 165,000 & 142,900 & 197,000 & 80,600 & 122,700 \\
\hline Al & & & 14,500 & 21,600 & 18,600 & 24,300 & 44,000 & 11,000 & 23,000 \\
\hline \multicolumn{10}{|l|}{$\mathrm{Fe}$} \\
\hline $\mathrm{Cr}$ & & & 17,500 & 1,831 & & & 1,300 & & \\
\hline \multicolumn{10}{|l|}{$\mathrm{Bi}, \mathrm{La}, \mathrm{Ni}$} \\
\hline$\% \mathrm{H}_{2} \mathrm{O}$ & 39.4 & 36.1 & 40.1 & 36.9 & 35.9 & 47.2 & 27.0 & 64.9 & 55.4 \\
\hline $\mathrm{NO}_{3}$ & 81,700 & 86,000 & 303,000 & 304,000 & 266,000 & 191,700 & 209,500 & 66,262 & 137,300 \\
\hline $\mathrm{CO}_{3}$ & & & & & & 19,000 & 24,100 & & \\
\hline $\mathrm{PO}_{4}$ & 93,600 & 96,900 & & & & & & & \\
\hline $\mathrm{SO}_{4}$ & & & & 11,800 & 33,732 & & & 50,200 & 17,402 \\
\hline$F$ & 10,000 & 11,000 & & & & & & & \\
\hline${ }^{137}$ cs $\mu \mathrm{Ci} / \mathrm{g}$ & & & 252. & & & & & & \\
\hline${ }^{90} \mathrm{Sr} \mu \mathrm{Ci} / \mathrm{g}$ & & & 1704 & & & & & & \\
\hline U & & & 10672 & & & & & & \\
\hline
\end{tabular}


WHC-SD-WM-DQ0-018, Rev. 0

Table 2

Waste Tanks with Thick Layers

Asterisk indicates priority tank(see Table 4)

\begin{tabular}{|c|c|}
\hline Waste Tank Number & Waste Type \\
\hline$A-101^{*}, A X-101^{*}$ & A2 Salt Slurry, Al Salt Cake \\
\hline$A-103, A X-103$ & Al Salt Cake \\
\hline B-105, B-106 & B Salt Cake \\
\hline $\begin{array}{l}\mathrm{B}-107, \mathrm{BX}-110^{*}, \mathrm{BX}-112, \\
\mathrm{C}-107\end{array}$ & $1 C$ \\
\hline BX-109*, TY-105 & UR \\
\hline $\begin{array}{l}\text { BX-111, } \\
\text { BY-101, BY-102, } \\
\text { BY-103, BY-107, BY-109, } \\
\text { BY-111, BY-112 }\end{array}$ & BY Salt Cake \\
\hline B104*, BY-105* & BY Salt Cake, PFeCN2 \\
\hline BY-106 & $\mathrm{FeCN}$ \\
\hline BY -108 & PFeCN1 \\
\hline BY $-110 *$ & PFeCN1, BY Salt Cake \\
\hline $\begin{array}{l}S-105, S-106, S-108, \\
S-109, S-112, S X-102, \\
S X-105, U-106\end{array}$ & SI Salt Cake \\
\hline$S-102, S-103$ & S1 Salt Cake, S2 Salt Slurry \\
\hline$S-110^{*}$ & S1 Salt Cake, $R$ \\
\hline$S X-103, S X-104^{*}$ & Sl Salt Cake, R1 \\
\hline$U-109 *, U-111$ & S1 Salt Cake, S2 Salt Slurry \\
\hline$S X-106$ & S2 Salt S1urry \\
\hline$U-107$ & S2 Salt Slurry, MW \\
\hline $\begin{array}{l}\text { TX-102, TX-103, TX-105, } \\
\text { TX-106, TX-108, TX-110, } \\
\text { TX-111*, TX-113, TX-114, } \\
\text { TX-115, TX-118* }\end{array}$ & T2 Salt Cake \\
\hline TX-112, TY-101 & T1 Salt Cake \\
\hline TX-116*, TX-117 & T2 Salt Cake, T1 Salt Cake \\
\hline$T X-109$ & $1 \mathrm{Cl}$ \\
\hline
\end{tabular}


WHC-SD-WM-DQ0-018, Rev. 0

Table 3

Waste Tanks with Shallow Single Wastes or

Waste Available for Top Augers

Asterisk indicates priority tank (see Table 4)

\begin{tabular}{||l|l|}
\hline \multicolumn{1}{|c|}{ Waste Tank Number } & \multicolumn{1}{|c|}{ Waste Type } \\
\hline \hline A-104 & AR \\
\hline B-108* & B Salt Cake \\
\hline $\begin{array}{l}\text { B-203, B-204, T-201, T-202, } \\
\text { T-203, T-204 }\end{array}$ & 224 \\
\hline BX-108 & IC \\
\hline C-201, C-202, C-203, C-204 & MW \\
\hline SX-108* & R2, (R1) \\
\hline$U-201$, U-202, U-203, U-204 & CWR \\
\hline T-101 & CWR2 \\
\hline T-108*, T-109 & T1 Salt Cake \\
\hline TY-104 & UR \\
\hline T-112 & 2C2 \\
\hline TY-101 & ICFeCN \\
\hline$U-112$ & Unknown \\
\hline
\end{tabular}


WHC-SD-WM-DQ0-018, Rev. 0

\subsection{Decision Rules}

A logic diagram is presented as Figure 1. Minor decisions involve determination of the sampling method for historical evaluation. The key decision rules combine in a gateway review of analytical data from the segment selected. Using the minimum values in Table 1, analytes are 1 isted until $85 \%$ of the total mass for the waste type is included. If the means for the analytical values for those analytes are $\geq 10 \%$ of the Table 1 value, then the layering and waste type identification are considered acceptable. Essentially, the broad criteria established for passing this initial review allows all waste types to be more thoroughly assessed and compared against historical values. However, this criteria will exclude the wastes that can easily be identified as being incorrectly selected for comparison. Once past the gateway, further assessment using an analysis of variance will be done. (Note: It is not the intent of this document to describe the more sophisticated statistical comparison of historical versus analytical data; however, technical studies will be made comparing the means from both sources, as well as the variability, then quantifying the error.) If the gateway criteria are not met, then there is a problem either with waste type identification or location specification. At this point, information from other segments is reviewed, as well as the model, to determine if location is the problem. Alternative segments may be identified and selected to represent the waste type if they pass a subsequent gateway test. If no segments pass the gateway test with regard to the waste type's predicted location and composition, the data will be re-examined. Other waste type composition will be examined, and assumptions about the tank configuration and process history will be reviewed. Analysis of variance and hypothesis testing methods wi11 not proceed without further direction.

Core composite samples will be taken, analyzed, and the results examined against predicted values using an analysis of variance (ANOVA) method. Should a segment pass the gateway, but be out of place with respect to the predicted location, further assessment of the data will proceed, with the spatial (layering) model results coming under scrutiny.

\section{Error Tolerance}

For each measurement of a fingerprint analyte, a determination will be made whether or not the sample under investigation coincides with predictions from historical data. Table 1 indicates that these historical predictions may fall within wide ranges. In order to el iminate detailed analysis on sample materials that are clearly not from a predicted location/waste type a minimum ratio of analytical to historical values is established at 0.1 . While this limiting ratio may allow further analytical expense on a sample that displays a "false positive," that circumstance can be addressed in the more detailed statistical review of the sample. However, the limiting ratio will have prevented most inapplicable analyses.

Since historical data with error estimates will be used by a wide variety of customers, it is difficult to specify the acceptable limits of uncertainty initially. Indeed, part of the purpose of this DQO is to provide the requisite data for the formation of those initial estimates of uncertainty. Any information obtained from subsequent sampling will be factored into a determination of error specific to the waste type. If that 


\section{Historical Data Analysis Logic}

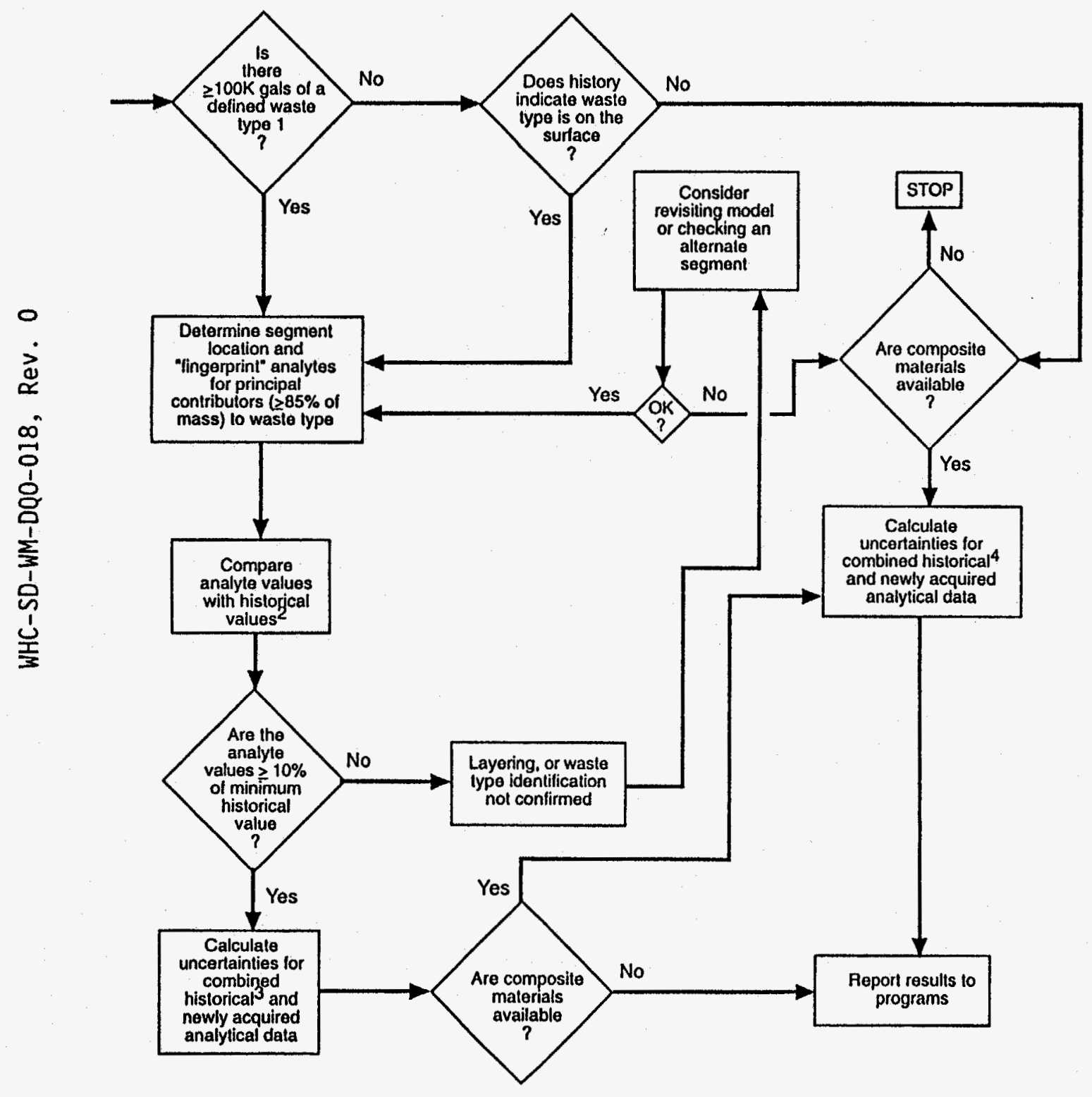

1. Based on $23 \mathrm{~m}$ (75 $\mathrm{fl}$ ) diameter tank lo assure existence of single waste type in $48 \mathrm{~cm}$ (19 in.) segment. Modity for smaller tank.

2. All waste type "fingerprint" analytes must be present.

3. Values as published in "Hanford Defined Wastes: Chemical and Radionuclide Compositions," Agnew 1994

4. Values as published in "Historical Tank Content Estimates," Agnew 1994-95 
newly determined error is still insufficient for customers in their decisionmaking processes, the action is to pursue more information about the desired waste type. This action will be done using acceptable alternate tanks of the same waste type (listed in Table 4) until the level of uncertainty meets the desired need, or an alternate acceptable means of meeting the requirement is found. In many cases, several tanks with multiple waste types have been specified for sampling. Comparison of analytical results from different tanks with the same waste type will aid quantifying the uncertainty associated with the waste type. All tanks identified on Table 4 (even the alternates) will be sampled per this DQO, until the waste type becomes so well defined and documented that it is removed from the tables in subsequent revisions.

The priorities assigned in Table 4 have three levels. The earliest tanks to be sampled are Priority 1. They provide key information addressing safety issues and supporting the improvement of grouping models and historical estimates. There are no safety issues associated with these tanks which would constrain sampling at this time. Priority 2 tanks are those which support only safety or model evaluation, or tanks which support both, but which may be delayed in sampling because of potential flammable gas generation. Priority 3 tanks include those which support only one group of issues and are delayed in sampling. Tank sampling optimization was also a factor in assignment of priority--multiple tanks in a single farm may be sampled more efficiently in a single opportunity window.

In order to help quantify spatial and analytical uncertainty, a minimum of two cores are needed, with duplicate analyses provided by the Taboratories on each sample. Efforts should be made to obtain thick layered segments from widely separated areas of the tank (i.e., one from the center, and one or two (or more) from diametrically opposite sides of the tank).

In terms of laboratory methodology and desired levels of analytical uncertainty, each measurement is to be performed at the normal laboratory quality level as defined in their Quality Assurance Plan (HASQAP, 1994). Those analyses used to confirm fingerprint analytes are to be completed for the full range of analytes available from the method. This request is in the interest of cost savings from having to run the analysis twice (once for gateway approval, then once for detailed statistical comparison). Any supplemental data obtained gratuitously with data specifically requested (e.g., metals from ICP, oxyanions from IC, or radionuclides from GEA) are to be reported with the requested analytes.

The detailed statistical analysis referred to throughout this $D Q 0$ includes independent work to obtain uncertainty values for the published Historical Tank Content Estimates (Agnew, 1994b). The result of that work will be publication of both a mean and error estimate for the historical data, represented by $\bar{x}_{H}$ and $s_{H}$. The data presented as a result of this DQO will also consist of a mean and error estimate for the sample, represented by $\bar{x}_{s}$ and $s_{s}$. Comparison of the two data sets wi11 be done by computing a $95 \%$ Confidence Interval on the difference between $\bar{x}_{H}$ and $\bar{x}_{s}$, using a variance of

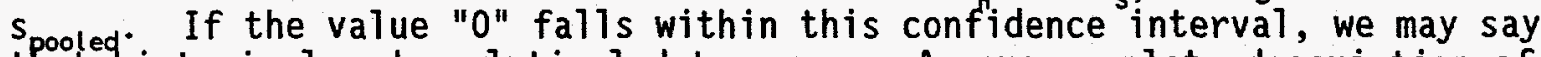
that historical and analytical data agree. A more complete description of this method and limitations of use is being developed by Pacific Northwest Laboratory. 


\subsection{Optimization Guidelines}

A11 information gained through this Data Quality Objective is to be maintained in a dynamic form such that additional information regarding a specific waste type is used to update previous uncertainty determinations. Analysis of variability is to be performed each time new data is provided. This practice will result in a continual improvement in knowledge of the waste types and total tank contents.

One of the principal constraints with regard to interpreting the sampling results is that the samples obtained from under the tank risers have the greatest probability of providing biased results. Singular materials, blockages or obstructions causing recovery problems, or atypical inclusions in the waste are much more likely to be observed around the riser, where access to the tank was provided. Sampling technology that addresses this problem would help optimize the quality of information obtained from this DQO.

A method for interrogating waste samples during, or immediately after extrusion in the hot cell would significantly improve the quality of information obtained from this DQO by reducing the time 1 ag between sampling and analysis. Methods that can detect, differentiate, and quantify metal ions are of interest, particularly laser-based spectroscopy. 
WHC-SD-WM-DQ0-018, Rev. 0

Table 4. Priority Tanks to be Sampled for Historical Evaluation

\begin{tabular}{|c|c|c|c|}
\hline Tank & $\begin{array}{l}\text { Preferred } \\
\text { Sample Type } \\
\end{array}$ & Priority & $\begin{array}{l}\text { Acceptable al ternate tanks } \\
\text { Underlining indicates most favorable } \\
\end{array}$ \\
\hline$A-101$ & Core & 2 & A-103 \\
\hline$A X-101$ & Core & 2 & $A X-103$ \\
\hline $\mathrm{B}-108$ & Auger & 3 & $\mathrm{~B}-105, \mathrm{~B}-106$ \\
\hline BX-109 & Core & 1 & TY-104 \\
\hline$B X-110$ & $\begin{array}{l}\text { Auger and } \\
\text { liquid grab }\end{array}$ & 3 & $\mathrm{~B}-107, \mathrm{BX}-112, \mathrm{TX}-109$ \\
\hline BY-104 & Core & 1 & $\begin{array}{l}\text { BY-101, BY-103, BY-106, BY-107, BY-108, BY-111, } \\
\text { BY-112 }\end{array}$ \\
\hline BY-105 & Core & 1 & $\begin{array}{l}\text { BY-101, BY-103, BY-106, BY-107, BY-108, BY-111, } \\
\text { BY-112 }\end{array}$ \\
\hline BY -110 & Core & 1 & $\begin{array}{l}\text { BY-101, BY-103, BY-106, BY-107, BY-108, BY-111, } \\
\text { BY-112 }\end{array}$ \\
\hline SX-104 & Core & 2 & SX-103, S-112, SX-102, SX-105, U-106 \\
\hline$S X-108$ & Auger & 3 & $\underline{S X-103}, S-112, S X-102, S X-105, U-106$ \\
\hline$S-110$ & Core & 3 & SX-103, S-112, SX-102, SX-105, U-106 \\
\hline$U-109$ & $\begin{array}{l}\text { Auger, core, } \\
\text { and liquid grab }\end{array}$ & 2 & $\frac{S-102}{S-108}, \frac{S-103}{S-109}, U-111, S X-106, S-105, S-106$ \\
\hline$T-108$ & Auger & 2 & $\begin{array}{l}\text { TX-112, TX-102, TX-103, TX-105, TX-106, T-108, } \\
T X-110, T X-113, T X-114, T X-115\end{array}$ \\
\hline$T X-111$ & Core & 2 & $\begin{array}{l}\text { TX-112, TX-102, TY-103, TX-105, TX-106, T-108, } \\
T X-110, T X-113, T X-114, T X-115\end{array}$ \\
\hline$T X-118$ & Core & 2 & $\begin{array}{l}\text { TX-112, TX-102, TY-103, TX-105, TX-106, T-108, } \\
\text { TX-110, TX-113, TX-114, TX-115 } \\
\end{array}$ \\
\hline TX-116 & Core & 2 & $\underline{T X-117}$ \\
\hline B-104 & Core & 2 & $\begin{array}{l}\text { C-102, A-106, BX-102, TY-103 (Spatially complex } \\
\text { tanks--knowledge will help in heterogeneity } \\
\text { model evaluations) }\end{array}$ \\
\hline$S-107$ & Core & 2 & S-111, U-103, U-105 (Spatially complex tank) \\
\hline$S-101$ & Core & 3 & SX-101, U-102, U-108 (Spatially complex tank) \\
\hline$C-104$ & Core & 3 & $\begin{array}{l}\text { C-106 (Greatest vertical and horizontal } \\
\text { variability. Contains minimum of eight waste } \\
\text { types.) }\end{array}$ \\
\hline
\end{tabular}




\section{References}

Agnew, S. F., 1994a, Hanford Defined Wastes: Chemical and Radionuclide Compositions, LA-UR-94-2657, Los Alamos National Laboratories, Los Alamos, New Mexico.

Agnew, S. F., 1994b, TANK LAYER MODEL (TLM), Rev. I for Northeast, Southwest, and Northwest Quadrants, LA-UR-94-4269, Los Alamos National Laboratories, Los Alamos, New Mexico.

Brevick, C. H., 1994, Historical Tank Content Estimate for the Southwest Quadrant of the Hanford 200 West Areas, WHC-SD-WM-ER-352, Rev. 0, Westinghouse Hanford Company, Richland, Washington.

Brevick, C. H., 1994, Historical Tank Content Estimate for the Northeast Quadrant of the Hanford 200 East Areas, WHC-SD-WM-ER-349, Rev. 0, Westinghouse Hanford Company, Richland, Washington.

Brevick, C. H., 1995, Historical Tank Content Estimate for the Northwest Quadrant of the Hanford 200 East Areas, WHC-SD-WM-ER-351, Rev. 0, Westinghouse Hanford Company, Richland, Washington.

Hi11, J. G., Anderson, G. S., Simpson, B. C., 1995, The Sort on Radioactive Waste Type Mode7: A Method to Sort Single-Shell Tanks into Characteristic Groups, PNL-9814 Rev. 2, UC-721, Pacific Northwest Laboratory, Richland, Washington.

U. S. Department of Energy, Hanford Analytical Services Quality Assurance Plan (HASQAP), DOE/RL-94-55, Controlled Document-Originally Published May 31, 1994, Richland, Washington. 
WHC-SD-WM-DQ0-018, Rev. 0

\section{APPENDIX A}

The defined waste types are briefly described below, as identified in Tables 1 and 2 in the text. In several cases, the waste types originally described in either Agnew, 1994a, or Hill, et.al., 1995, have been consolidated and have a expansion of concentration range as a result of that consolidation.

MW - Metal waste from the bismuth phosphate process employed from 1944 through 1956

1C - First cycle decontamination waste from the bismuth phosphate process

2C - Second cycle decontamination waste from the bismuth phosphate process

224 - Lanthanum fluoride finishing waste

UR/TBP - Tri-Butyl Phosphate waste from solvent-based Uranium Recovery Operation

FeCN - $\quad$ Ferrocyanide waste created in a scavenging campaign, 1953-57

R - $\quad$ High leve1 REDOX waste generated from 1952 to 1956

CWR/A1 - Aluminum cladding waste from REDOX

CWP/Al - Aluminum cladding waste from PUREX

P - $\quad$ Purex high-activity, neutralized acid waste

B - $\quad$ B-Plant high level waste from waste fractionization process

CC - $\quad$ Complex concentrates; usually solutions that have TOCs greater than $10 \mathrm{~g} / \mathrm{L}$; usually associated with EDTA and HEDTA salts

AR - Waste from various washes of sludge in the AR Vault

Salt Cakes The average supernatant is calculated for each evaporator campaign and then used to define the corresponding saltcakes and salt slurries for those campaigns. They are identifiable in the first letters of their acronym either by special campaign (RSItCK and BY S1tCK) or by the evaporator used (BS1tCk, T1S1tCk, T2S1tCK, sisitCk, S2SitSir, A1S1t(Ck, and A2SitSir). 